\title{
THE CHILD WITNESS: RECONCILING THE IRRECONCILABLE
}

\author{
BY JAMES C. ROBB* AND LYNDA J. KORDYBAN**
}

This article canvasses the issues of competency, corroboration, hearsay and confrontation with respect to child witnesses, from both a legal and humanistic perspective. The authors survey the law from a historical perspective, through to recent changes in Bill C-15, in an attempt to reconcile the rights of an accused with those of child victims of sexual offences.

\section{TABLE OF CONTENTS}

I. INTRODUCTION

II. COMPETENCY $\ldots \ldots \ldots \ldots \ldots \ldots \ldots \ldots \ldots \ldots \ldots \ldots$

A. HISTORICAL BACKGROUND $\ldots \ldots \ldots \ldots \ldots \ldots \ldots$

B. CURRENT CASE LAW $\ldots \ldots \ldots \ldots \ldots \ldots \ldots \ldots \ldots$

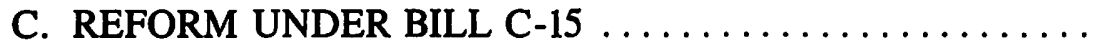

III. CORROBORATION $\ldots \ldots \ldots \ldots \ldots \ldots \ldots \ldots \ldots$

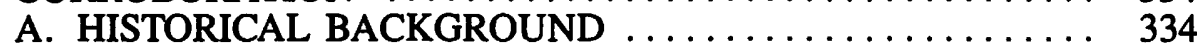

B. CURRENT CASE LAW $\ldots \ldots \ldots \ldots \ldots \ldots \ldots \ldots \ldots, 336$

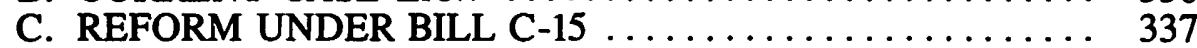

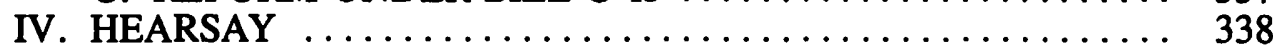

A. HISTORICAL BACKGROUND $\ldots \ldots \ldots \ldots \ldots \ldots \ldots \ldots, 338$

B. CURRENT CASE LAW $\ldots \ldots \ldots \ldots \ldots \ldots \ldots \ldots \ldots \ldots, 339$

C. REFORM UNDER BILL C-15 ................ 341

V. CONFRONTATION ..................... 345

A. HISTORICAL BACKGROUND ................ 345

B. CURRENT CASE LAW $\ldots \ldots \ldots \ldots \ldots \ldots \ldots \ldots \ldots, 346$

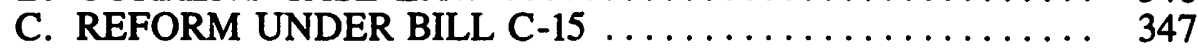

VI. CONCLUSION $\ldots \ldots \ldots \ldots \ldots \ldots \ldots \ldots \ldots \ldots \ldots, 352$

\section{INTRODUCTION}

1881, Robert Louis Stevenson, Child's Play (in "Virginibus Puerisque"): "It is when we make castles in the air and personate the leading character in our own romances that we retum to the spirit of our first years. In all the child's world of dim sensations, play is all in all. 'Making believe' is the gist of his whole life, and he cannot so much as take a walk except in character.

...One thing, at least, comes very clearly out of all these considerations, that whatever we are to expect at the hands of children, it should not be any peddling exactitude about matters of fact. They walk in a vain show, and among mists and rainbows: they are passionate after dreams and unconcemed about realities; speech is a difficult art not wholly leamed; and there is nothing in their own tastes or purposes to teach them what we mean by abstract truthfulness . . . Show us a miserable unbreeched human entity, whose whole profession it is to take a tub for a fortified town and a shavingbrush for the deadly stiletto, and who passes three fourths of his time in a dream and the rest in open self-deception, and we expect him to be as nice upon a matter of facts as a scientific expert bearing evidence! Upon my heart, I think it less than decent." I

This quotation illustrates judicially and societally held beliefs about a particular class of witness - the child witness. These beliefs, which view children as

* Assoc. Professor of Law, University of Alberta

** B.S.W., M.Ed. (Counselling Psychology)

1. Wigmore, On Evidence, 3rd ed. (1940), Vol. 2, 509. 
inadequate witnesses, are being challenged. The new focus on the child witness stems from four developments:

1. The concern about the prevalence of child abuse (both physical and sexual). The Report of the Committee on Sexual Offences (the Badgley Report) states that, based upon a national survey, about one in two females, and one in three males have been victims of sexual abuse. ${ }^{2}$ In the United States, estimates have been made that 100,000 to 500,000 cases of child abuse will occur in any given year. ${ }^{3}$

2. A natural consequence of the first has been a challenge to the assumption that the primary source of protection for the child must stem from the family and that state intervention is to be minimal and least intrusive. Given a belief that familial child abuse is prevalent, it follows that state intervention is required. The proliferation of child abuse laws largely indicates that the lobby for stronger intervention has been successful.

3. The criminal law component of state intervention is viewed as flawed. Much of the writing (such as the Badgley Report) perceives strong impediments to obtaining convictions in cases of child abuse. The result is pressure to change or relax rules of evidence which inhibit convictions.

4. Central to the pressure for reform is the challenge to the assumption that children as witnesses are less reliable than adult witnesses. Indeed, it is presently posited that children are at least as credible as adults, if not more so. ${ }^{4}$ Thus, the focus of reform is to ensure equal treatment of child/adult witnesses, and to some extent, to achieve a removal or modification of traditional safeguards for accused persons.

One result is the controversial reforms contained in Bill C-15. ${ }^{5}$ This paper will examine four rules that concern the child witness: (1) competency, (2) requirements of corroboration, (3) usage of hearsay evidence, and (4) rights of confrontation. These rules will be explored in three ways. Firstly, a brief historical review of each rule will be set out. It is important to understand the historical and social context in which rules are created because, as Thayer noted, rules of evidence are built upon prevailing standards of knowledge and reasoning. As our knowledge and standards of reasoning change, so should the law. ${ }^{6}$ Secondly, current case law will be examined to establish present rules and thereby focus the extent of change created by Bill C-15. Finally, the provisions of Bill C-15 will be examined to identify the issues that the Courts will have to deal with in interpreting and applying the new legislation.

2. (1986), Vol. 1, at p. 193.

3. V. DeFrancis, "Protecting the Child Victims of Sex Crimes Committed by Adults" (1979), Colorado American, at p. 216; J. Yun, "A Comprehensive Approach to Child Hearsay Statements in Sex Abuse Cases"' (1983) 83 Colum. L. Rev. 1745, n.1.

4. A central theme of the Badgley Report, supra, n.2; see also: State v. Myat 237 P. 2d 836 (1985), at p. 841, where this was expressly accepted.

5. An Act to Amend the Criminal Code and the Canada Evidence Act, proclaimed January 1, 1988.

6. Thayer, Preliminary Treatise on Evidence at the Common Law (1898), at pp. 508-538. 


\section{COMPETENCY}

\section{A. HISTORICAL BACKGROUND}

At common law, witnesses had to be sworn in order to give evidence.' Persons with an interest in the outcome of the case (parties to the action, including an accused in a criminal case, their spouses, and those with a financial interest in the outcome) were prohibited from taking the oath and thus giving testimony. In theory, their interest in the outcome was such that no credible evidence could be expected from them. ${ }^{8}$ This prohibition has been removed by statute. ${ }^{9}$

Assuming legal competence, witnesses could not be sworn if they suffered from an organic incapacity to understand the nature and consequence of the oath. That required a belief in an anthropomorphic god, a belief in divine consequences for not telling the truth, and an understanding of the specific duty to tell the truth. ${ }^{10}$ The classic list of persons who were considered incapable of this understanding included the insane and children of tender years. "It was not to be taken that they were automatically prevented from taking the oath. Rather, they were to be examined by the Judge to determine whether they understood the nature and consequence of taking the oath. ${ }^{12}$

With respect to children, the concept of the child of tender years flows from antiquated notions of ages of competency. According to Blackstone, a girl could be betrothed at age 7, acquire dower rights at 9 , and marry at age $12 .{ }^{13}$ Vestiges of these old rules of competency are still to be found, for example, s. 12 of the Criminal Code of Canada states that a child under the age of 12 is deemed incompetent to commit a crime.

As for testifying, early canon law established that the child must have reached the age of puberty, which was later modified by early common law courts to age seven ${ }^{14}$ Over a period of time the Courts relaxed the rigidity of the rule. First, it was established that there was no minimum age at which a child was presumptively incompetent, but rather, the only test was understanding the nature and consequences of the oath. ${ }^{15}$ As an example, in $R$. v. Brasier, a five year old child was sworn. ${ }^{16}$ Secondly, the Courts were permitted to give religious instruction to the child, and if accepted (apparently understood), the child could be sworn. ${ }^{17}$

Eventually, legislation in both England and Canada provided that if a child could not be swom, but appeared to have sufficient intelligence to testify and understand the duty to tell the truth in Court, the evidence could be admitted. By the turn of the 20th century, the law was that a child of tender years was to be examined as to competence to take the oath (requiring a belief in a supreme being and divine sanc-

7. Wright v. Tatham (1837), 112 E.R. 488, at p. 515.

8. Phipson, On Evidence, 13th ed. (1982), at pp. 691-692.

9. Canada Evidence Act, s.4.

10. Archbold, Criminal Pleadings and Practice, 42nd ed., (1985), at p. 379.

11. R. v. Dunning [1965] Crim. L.R. 372; R. v. Williams (1835) 7 C \& P 320.

12. Archbold, supra, n.10.

13. Blackstone, Commentaries On the Laws of England, (1876), Vol. 4, at pp. 20-22.

14. R. v. Brasier (1779) East 443.

15. Young v. Slaugterford (1709), 11 Mod. Rep. 228; R. v. Moscovitch (1958), 42 Cr. App. R. 153.

16. As reported in (1779) East 443.

17. R. v. Hawke (1975), 22 C.C.C. (2d) 19, at p. 29, per Dubin, J.A. 
tion), but if incompetent, could nevertheless be heard. In the latter event, however, corroboration was necessary to obtain a conviction..$^{18}$

\section{B. CURRENT CASE LAW}

\section{C-15):}

\section{The statutory rule was found in s. 16 of the Canada Evidence Act (prior to Bill}

Section 16 (1) In any legal proceeding where a child of tender years is offered as a witness, and such child does not, in the opinion of judges, justice or other presiding officer, understand the nature of an oath, the evidence of such child may be received, though not given upon oath, if in the opinion of the judge, may be, the child is possessed of sufficient intelligence to justify the reception of the evidence, and understands the duty of speaking the truth.

(2) No case shall be decided upon such evidence alone, and it must be corroborated by some other material evidence.

This section had three components: (a) a child of tender years; (b) must be examined to determine whether the child understands the nature of the oath; and, (c) if failing the test, the child may be heard; provided the child is of sufficient intelligence and understands the duty of telling the truth. In the latter event, the testimony must be corroborated. Each component will be looked at more fully.

\section{Child of Tender Years}

The term is not defined by s.16. In England, the term was held to mean a child of fourteen years, ${ }^{19}$ although a slightly earlier case had set the watershed at 8-10 years. ${ }^{20}$ In $R$. v. Wallwork, it was stated that it is undesirable that a child as young as five should be called as a witness at all. ${ }^{21}$ This, however, has not been accepted in Canada.

The Supreme Court of Canada noted that the statute was silent on the meaning. Anglin, C.J.C. stated:

The term "child of tender years" is not defined. Of no ordinary child over seven years of age can it be sagely predicted, from his mere appearance, that he does not understand the nature of an oath. Such a child may be convicted of crime . . . A very brief inquiry may suffice to satisfy the judge on this point. But some inquiry would seem to be indispensable. ${ }^{22}$

This suggests that a child under seven would be presumed to be incapable of understanding the oath. However, an upper age limit at which a child must be examined was not established, although the generally accepted age is fourteen. In $R$. v. Horsburgh, the reasoning of the Ontario Court of Appeal was that a child of less than fourteen years is presumed competent for the purposes of criminal liability. A child between the ages of seven and fourteen could be prosecuted only if the trial judge was satisfied that the child understood the nature and consequences of the conduct in question. Accordingly, the Court stated that similar reasoning should apply to presumptive capacity to take an oath. ${ }^{23}$ In this way a firm age was established. The problem with this reasoning is three-fold: (i) unlike the provision for criminal liability, the Canada Evidence Act was silent on the question of a

18. Canada Evidence Act, s.16(2); Criminal Code of Canada, s.586.

19. R. v. Khan (1981), 73, Cr. App. R. 190.

20. R. v. Hayes (1977), 64 Cr. App. R. 190.

21. (1958), 42 Cr. App. R. 153.

22. Sankey v. R. [1927] S.C.R. 436, at p. 439.

23. [1966] 1 O.R. 739, at p. 746, per Evans, J.A. See also R. v. Dyer (1972), 5 C.C.C. (2d) 376, at p. 378, per Maclean, J.A. 
specific age; (ii) the term "tender years" implies considerable youth which accorded with the common law view and; (iii) the age was eventually reduced to twelve, which has not been paralleled by the interpretation of the term in question. ${ }^{24}$ Generally, the age of fourteen has remained uncontested. The reason, in part, may be found in what the Courts have done recently to the test for competency that has reduced the importance of defining a child of tender years.

\section{Understands the Nature of Oath}

The taking of the oath was predicated upon a religious belief: belief in a supreme being and divine retribution. The alternative to the oath (i.e., affirmation) is premised upon a sufficient understanding of religion to found a conscientious objection to taking the oath. ${ }^{25}$ Section 16 strongly suggested a distinction was to be drawn between a requisite religious belief and an understanding of the duty to tell the truth. Simply understanding the duty to tell the truth permits the child to give unsworn testimony. The dual nature of the test was expressed clearly in Sankey v. $R$.:

Now it is quite as much the duty of the presiding Judge to ascertain by appropriate methods whether or not a child offered as a witness does, or does not, understand the nature of an oath, as it is to satisfy himself of the intelligence of such child and his appreciation of the duty of speaking the truth. On both points alike he is required by the statute to form an opinion; as to both he is entrusted with discretion, to be exercised judicially and upon reasonable grounds. 26

However, the recent cases have stripped s. 16 of its religious connotation. Firstly, s. 16 required an understanding of the "nature of an oath" and not its consequences. In $R$. v. Bannerman, it was held that it was not necessary to find a belief in divine retribution. ${ }^{27}$ What was important was that the child understood the moral obligation of telling the truth. ${ }^{28}$ In the year following Bannerman, the Supreme Court confirmed that it was the moral obligation to tell the truth that would be the telling point.$^{29}$ Thus, provided there was a belief in a supreme being, ${ }^{30}$ the hurdle of understanding the nature of an oath was made relatively easy.

It was to become easier. In $R$. v. Fletcher, the Ontario Court of Appeal ruled that no inquiry need be made about belief in a supreme being, because in a secular society it was doubtful that many adults could satisfy the requirement. Therefore, children could be sworn provided they understood the duty to tell the truth. ${ }^{31}$ This can be accomplished by a cursory examination of the child. The reasoning was adopted by de Weerdt J. in $R$. v. Pootoogook, where it was reiterated that while it may be helpful to inquire into the child's religious background, it is unnecessary if the judge is satisfied that the child understands the moral obligation to tell the truth. Furthermore, the judge may lead the child in the questioning, and while

24. Criminal Code of Canada, s. 12 which actually raised the age from seven. Section 13, which established the seven to fourteen years of age bracket was repealed 1980-81-82-83, c.110, s.72.

25. R. v. Deakin (1911), 16 B.C.R. 271, at pp. 272-273, per Macdonald, C.J.A.; Canada Evidence Act, s. 14.

26. Supra, n.22.

27. (1966) 55 W.W.R. 257; aff'd. 57 W.W.R. 736.

28. R. v. Dinsmore, [1974] 5 W.W.R. 257; aff'd. 57 W.W.R. 736.

29. Reference Re R. v. Truscott, [1967] S.C.R. 309, at p. 368.

30. R. v. Budin (1981), 20 C.R. (3d) 86.

31. (1983), 1 C.C.C. (3d) 370, at pp. 376-7, per MacKinnon, A.C.J. The case is also notable for examples of relatively cursory inquiries which were deemed to meet the minimum standard. 
counsel do not have a right to cross-examination, they may suggest questions to the judge. ${ }^{32}$

A slightly different approach was taken by the Alberta Court of Appeal in $R$. v. Connors. ${ }^{33}$ The secular reasoning in Fletcher was adopted, but the Court determined that a child understanding the moral obligation to tell the truth could be affirmed. This means that the requirement for a conscientious objection (in $\mathrm{s} .15$ of the Canada Evidence Act) need not be observed. ${ }^{34}$ By permitting affirmation, rather than the oath, the Court may have been implying that there is still a religious component to the oath. However, a lack of understanding of the component simply results in affirmation provided there is an understanding of the duty to tell the truth.

\section{Understanding the Duty to Tell the Truth}

The test for hearing unsworn testimony was that the child be of sufficient intelligence to justify the reception of the evidence and understand the duty to tell the truth. McCormick suggests that this test means "whether the witness has intelligence enough to make it worthwhile hearing him at all and whether he feels a duty to tell the truth . . ." ${ }^{35}$ The "intelligence" portion of the test would seem to mean the ability to understand questions and give intelligent answers. In short, an ability to communicate evidence was required. The "duty to tell the truth" would mean understanding the moral obligation to tell the truth. ${ }^{36} \mathrm{~A}$ frequent question is how this differs from understanding the moral obligation to tell the truth for the purpose of giving sworn or affirmed evidence?

While most decisions are vague on this issue, it was directly addressed by the Ontario Court of Appeal in $R$. v. Khan ${ }^{37}$ The child witness was 4 years and 8 months old at the time of testifying. The Court held that to give sworn testimony required an appreciation of the solemnity of the occasion, and the added responsibility to tell the truth over and above the duty to tell the truth which is an ordinary duty of normal social conduct. For unsworn testimony, the test is whether the child understands the duty to tell the truth in terms of ordinary social conduct, that is, does the child understand the difference between the truth and a lie, that it is wrong to lie, the necessity to tell the truth, and promises to do so. ${ }^{38}$

The distinction, therefore, turns on the fine point of whether there is an understanding of the solemnity of the occasion. Stripping s.16(1) of its religious connotation renders it relatively easy to hear sworn or affirmed evidence, thus avoiding the necessity for corroboration.

\section{REFORM UNDER BILL C-15}

Although the collapsed distinction between the test for giving swom and unsworn testimony results from judicial legerdemain, the result is realistic in a more secular

32. [1984] N.W.T.R. 165 .

33. (1986), 71 A.R. 78.

34. This was the express ruling in an earlier case not cited in Connors. See: $R$. v. Dawson [1968] 4 C.C.C. 33.

35. Handbook of the Law of Evidence, at p. 140, as cited in Hawke, supra, n.17.

36. Delisle, Evidence: Principles and Problems (1984), at p. 115.

37. (1988), 42 C.C.C. (3d) 197.

38. Ibid, at p. 11-12. 
world and has the benefit of simplicity. It also accords with the currently held view that children as a class of witness are as capable of telling the truth as adults. It is surprising, therefore, that Bill C-15 may create more complexity. The rules contained in the revisions of s.16 of the Canada Evidence Act, may be summarized by the following three points:

1. The age of fourteen remains the watershed (s.16(1)). The term "child of tender years" is eliminated, but the age of 14 as the age of presumptive capacity is expressly stated. This is important, not only because the arbitrary age of presumptive capacity is maintained, but because the section establishes different rights for the over and under fourteen year old witness.

2. An inquiry for a child under the age of 14 remains automatic (s.16(1)). If the witness is older than 14 , one of the parties must challenge the mental capacity of the witness. The new s.16(5) states that the burden of satisfying the Court that there is an issue, if the child is older than fourteen, is upon the challenger. This simply reiterates the present rules for challenging the competency of witnesses who are over the age of fourteen in the sense that there must be a challenger. However, in $R$. v. Hawke, the Ont. C.A. approved Wigmore's view that any one of the following would suffice to create the obligation to inquire: a simple challenge, extrinsic evidence offered by the challenger, or the fact that the witness was undergoing treatment ${ }^{39}$ The new $\mathrm{s.} 16$ will modify this slightly. A simple challenge, if the witness is over fourteen, will not suffice.

The section creates two procedures: (a) if the child is under fourteen, an inquiry is mandatory; and (b) if the child is over fourteen, the party objecting must establish that there is an issue of competency. In the latter event, a voir dire is required (which normally would be conducted in the presence of the jury $)^{40}$ to determine whether an inquiry will be made. The challenger could offer extrinsic evidence relevant to the mental capacity of the witness, and it is doubtful that such evidence could be refused. ${ }^{41}$ The more difficult question is whether anything short of extrinsic evidence will suffice, such as cogent information offered by counsel that reason to doubt capacity exists. In the past, the age and demeanour of the witness has been held to justify the judge embarking on an inquiry. ${ }^{42}$

3. The dual test of understanding the nature of an oath and the ability to communicate is reinforced (s.16(1)). The new section still insists upon a dual test, and indeed, reinforces it.

It is important at this stage to note the precise effects of this formulation:

(a) If the child understands the nature of the oath (the solemnity of the occasion imposing the duty to tell the truth), and is able to communicate, the child is swom (s.16(2)).

(b) If the child does not understand the nature of the oath but is of sufficient intelligence to justify reception of the evidence (which means able to understand the simple form of questions anticipated and able to understandably communicate answers) ${ }^{43}$ then the witness may testify upon a promise to tell the truth.

(c) If neither test is met, the child is not permitted to testify.

39. Supra, n.17, at p. 27, per Dubin, J.A.

40. This is to enable the jury to assess credibility; see Phipson, supra, n.8 at pp. 694-5; Archbold, supra, n. 10, at p. $373 ;$ R. v. Hawke, supra, n.17.

41. R. v. Dyer, supra, n.17.

42. R. v. Dyer, supra, n.23.

43. R. v. Khan, supra, n.37, at p. 13. 
The reason why Parliament would not have expressed a single test of understanding the duty to tell the truth is a mystery. The Law Reform Commission of Victoria recommended a simple test of being of sufficient intelligence to justify reception of evidence, and understanding the duty to tell the truth..$^{44}$

(d) This means that a child may give evidence without understanding the duty to tell the truth, without being sworn, and without the necessity of corroboration - A child may now give evidence upon a promise to tell the truth. However, that situation can arise only if the trial judge is not satisfied that the child understands the moral obligation to tell the truth (the nature of an oath)!

Under the old s.16, the test for unsworn evidence was sufficiency of intelligence and understanding the duty of speaking the truth. The emphasized words have been repealed by the new section. Thus the test for giving evidence upon a promise to tell the truth will be sufficiency of intelligence only. Its controversial feature is that corroboration will not be required, although it is not evidence under oath, and perjury is not an available sanction (it would not be for a child under age twelve in any event). The new provision seems to adopt Wigmore's view that children's testimony should simply be accepted. Wigmore was of the view that children's testimony was suspect, but that it would be better to permit it, rather than deal with antiquated notions of competency. The critical issue was weight. ${ }^{45}$

\section{CORROBORATION}

The requirement for corroboration of a child's testimony flowed from three sources:

1. The statutory requirement that no conviction may be founded upon the uncorroborated evidence of a single witness (whether child or aduit). The list in the Criminal Code includes: treason (s.46), perjury (s.120), false statements (s.122), procuring (s.195), feigned marriages (s.256), and forgery (s.325).

2. The Criminal Code (s.586), and the Canada Evidence Act (s.16(2)) each required corroboration if the case is dependent upon the testimony of an unsworn child.

3. By common law, a jury was to be warned of the dangers of convicting upon the testimony of a suspect witness in the absence of corroboration. The list of suspect classes included accomplices ${ }^{46}$ (including child victims in sexual assault cases), ${ }^{47}$ complainants in sexual offence cases, ${ }^{48}$ witnesses of disreputable character ${ }^{49}$ and children who have given sworn testimony. ${ }^{50}$

\section{A. HISTORICAL BACKGROUND}

The concerns with respect to a child's testimony were several. Firstly, if the child is unsworn, there is nothing to bind his or her conscience. Secondly, there was a

44. Sexual Offences Against Children, Discussion Paper No. 12 (March, 1988).

45. Supra, n.1.

46. R. v. Baskerville, [1916] 2 K.B. 658.

47. R. v. Horsburgh, supra, n. 23 at pp. where it was stated that the definition of accomplice means one who is participis criminis (i.e., one who shares or cooperates in the crime).

48. R. v. Henry (1968), 53 Cr. App. R. 150, at p. 153.

49. R. v. Deacon (1947), 89 C.C.C. 1. However, the thrust of recent case law has been that the requirement is not automatic, but that the circumstances of each case must be examined: see Maxwell v. $R$. (1979), 47 C.C.C. (2d) 65.

50. This was the rule where the child was accuser. See: $R$. v. Mitchell (1952), 36 Cr. App. R. 79; $R$. v. Kendall (1962), 132 C.C.C. 216; Horsburgh v. R., supra, n.23. 
belief that children are mentally immature. The Supreme Court of Canada indicated that four concerns arise: (a) capacity of observation; (b) capacity to recollect; (c) capacity to understand questions put and frame intelligent answers; and (d) moral responsibility of the witness. ${ }^{51}$ Thirdly, there was a suspicion of the motives of girls as sexual complainants. In Mattouk v. Massad it was stated:

It is now a commonplace that in judicial inquiries it is very dangerous to accept the uncorroborated
story of girls of this age [referring to a fifteen year old complainant] in charging men with sexual
intercourse. No doubt, there is no law against believing them, but in nearly all cases justice requires
such caution in accepting their story that a practical precept has become almost a rule of law. ${ }^{52}$

The frailty of such judgments is that they are not based upon empirical evidence but rather upon assumptions about children and adolescents. Undoubtedly, these concerns find their roots in history. Partly, it is a reaction to infamous trials, the most famous of which were the Salem witch trials in 1692. It is widely thought that several young girls maliciously accused a slave woman of witchcraft. The result was a chain reaction that led to hysterical allegations of witchcraft resulting in twenty hangings. This spawned a reaction against perceived abuses, and a suspicion of the motives of child witnesses. Interestingly, more current research indicates that 17th century populations (particularly children) were prone to ergotism, a kind of food poisoning, the symptoms of which include a feeling that ants are crawling under the skin, urine stoppage, and delirium. In short, the children may well have been ascribing a cause to their symptoms, identical to those which an adult would experience if suffering from the same disease. ${ }^{53}$

This ancient suspicion was bolstered by early psychological research that culminated in Freud's sexual fantasy theory, and in the theory that children are so prone to suggestibility, so incapable of distinguishing between fantasy and reality, that their evidence ought to be rejected entirely. This attitude is reflected in the rhetorical question posed by a noted Belgian psychologist, J. Varendonck, in 1911: "when are we going to give up, in all civilized nations, listening to children in Courts of law?" 54

It is only recently that such conclusions have been challenged, and the result is a major dichotomy of opinion. At the extremes of the debate are the opposite notions that children never (or at least rarely) lie about abuse and the notion that children will always lie, sometimes from malice, and sometimes to please someone else, such as the investigator, the parent, or the Court. At the heart of the debate is concern over the high incidence of child abuse versus the concern over what is perceived as a growing number of false accusations. ${ }^{55}$

Both extremes should be treated by the Courts with caution. Most researchers indicate that considerable research must still be done before concrete conclusions can be drawn. However, the present trends in research indicate a number of factors: (a) a child's testimony must be examined on a case by case basis; (b) that as a class of witness, children are no more prone to fabrication than adults; (c) that

51. R. v. Kendall, ibid, at p. 220 , per Judson, J.

52. [1943] A.C. 588, at p. 591.

53. G. Goodman, "Children's Testimony in Historical Perspective” (1984), 40 Jo. of Social Issues 9, at pp. 10-11.

54. Ibid.

55. For example, a recent conference of psychologists at the University of Utah resulted in widespread publicity conceming the growing number of false complaints - excerpt from the Arizona Republic, 10 Criminal Trial Lawyers Association Newsletter, p. 77. 
even young children have the ability of recall, though there may be a problem with free recall; (d) that questions to children must be direct and in familiar language; and (e) that suggestibility is not necessarily more of a problem with children than with adults. ${ }^{56}$ Thus, the current research would indicate that the Courts should not approach the problem of a child's testimony from a preconception that children as a class either do, or do not lie. Rather, the circumstances of the individual case should be assessed, including: (a) the adequacy and integrity of the pre-trial investigation process, (b) the presence or absence of parental or peer pressure, and (c) the knowledge of the child (for example many children by age five may know the rudiments of sexual anatomy, but not of sexual acts). ${ }^{57}$

\section{B. CURRENT CASE LAW}

The major development in corroboration occurred in the Supreme Court's decision in Vetrovec; Gala v. The Queen..$^{58}$ This landmark decision established two fundamental changes. Firstly, dealing with the accomplice category of witness, the Court held that falling within the suspect witness category does not automatically require a jury warning. Rather, the individual circumstances of the case must be considered, particularly if there is any reason to doubt the veracity of the witness beyond the mere fact that they fall within the suspect category. This same practical approach could clearly extend to the situation of the sworn child witness.

Secondly, the test for corroboration in $R$. v. Baskerville, requiring independent evidence implicating the accused in the commission of the crime on a material fact in issue, was discarded. Dickson, J., however, expressly confined his remarks to common law situations requiring a waming, and specifically did not deal with statutory requirements of corroboration. However, in $R$. v. Chayko, the Alberta Court of Appeal extended the reasoning to apply to the unsworn testimony of children. The majority stated that the test to be applied is the civil test of whether the corroborative evidence is capable of including a rational belief in the suspect testimony. ${ }^{59}$ Again, this approach accords with common sense.

Despite these advances, the view that children are suspect witnesses, even if sworn, remains strongly held. The House of Lords, in three major decisions, has ruled that children are a suspect class of witness. ${ }^{60} \mathrm{~A}$ full warning about the dangers of conviction remains obligatory. In Canada, a similar view was strongly expressed by the Manitoba Court of Appeal in R. v. Lang. ${ }^{61}$ The Court affirmed not only the need for a cautionary warning, but emphasized that it is not to be

56. B. Nurcombe, "The Child as Witness: Competency and Credibility" (1986), 25 Jo. of the Amer. Acad. of Child Psych. 4:478-80; G. B. Melton, "Children's Competency to Testify" (1981), 5 Law and Human Behavior, at p. 82; E.F. Loitus and G.M. Davies, "Distortions in the Memory of Children" (1984), 40 Jo. of Social Issues, at p. 62.

57. Lloyd, The Corroboration of Sexual Victimization of Children in Child Sexual Abuse Cases, (1982) at p. 105; State v. Myatt, supra, n.4; see also R. v. Khan, supra, n.37, at p. 19.

58. (1982) 67 C.C.C. (2d) 1.

59. (1985) 12 C.C.C. (3d) 156. The Alberta Court of Appeal also confirmed its reasoning in $R$. v. Jackson (1988), 58 Alta, L.R. (2d) 207 (Alta. C.A.). See also R. v. Larabie (1985), 5 C.C.C. (3d) 342.

60. D.P.P. v. Hester, [1973] A.C.; D.P.P. v. Kilbourne, [1973] 1 All E.R. 440; D.P.P. v. Spencer [1986] 2 All E.R. 928.

61. (1987), 46 Man. R. (2d) 135. 
ignored lightly. The court indicated that the critical question was whether there was a danger. If there was none, then the trier of fact may convict. However, if there was real danger, then the trier of fact may not act unreasonably by turning a deaf ear to the warning. ${ }^{62}$

\section{REFORM UNDER BILL C-15}

The current rules requiring corroboration are eliminated in four ways: (a) the new s.16 does not contain a requirement for corroboration (the old s.16(2) is repealed); (b) s.586 of the Criminal Code is repealed; and (c) the new s.246.4 of the Criminal Code provides that where an accused is charged under ss. 140 (sexual interference), 141 (invitation to sexual touching), 146 (sexual exploitation), 150 (incest), 167 (permitting sexual activity), 160 (corrupting children), 169 (indecent exposure), 195 (procuring), and/or 246.1-.3 (sexual assault), then corroboration is not required. Furthermore, the trial judge is not to instruct the jury that it is unsafe to convict in the absence of corroboration. (d) Section 246.5 abrogates the rules in relation to recent complaint that required that the credibility of the complainant be supported by evidence of a complaint made at the first reasonable opportunity.

In short, the new provisions eliminate the requirement (for enumerated offences) that corroboration is mandatory (i.e., no conviction possible without corroboration) where evidence is not given under oath or solemn affirmation. This would arise where the child's evidence is heard upon a promise to tell the truth.

Another controversial feature is the direction that a discretionary warning must not be given (i.e., that it is unsafe to convict, but the jury may do so if they believe the witness). This is clearly directed to altering the common law practice that called for a waming to juries in sexual cases involving child complainants, and represents a major departure from current Canadian and English authorities. It is a welcome change in that the old assumptions about children's veracity, as a class of witness, are largely unfounded. As Dickson, J. stated in Vetrovec (in the context of accomplices):

There is nothing inherent in the evidence of an accomplice which automatically renders him untrustworthy. To construct a universal rule singling out accomplices, then, is to fasten upon this branch of the law of evidence a blind and empty formalism. Rather than attempting to pigeonhole a witness into a category and then recite a ritualistic incantation, the trial judge might better direct his mind to the facts of the case, and thoroughly examine all factors which might impair the worth of a particular witness. If, in his judgment, the credit of the witness is such that the jury should be cautioned, then he may instruct accordingly. If, on the other hand, he believes the witness to be trustworthy, then, regardless of whether the witness is technically an "accomplice" no waming is necessary. 63

The same common sense approach could, and should, be applied to children. The difficult question is whether the prohibitive words of s.246.4 actually prevent this happening, in the sense that it forbids the caution being given to the jury. A literal application of s.246.4 would lead to that conclusion. That was the viewpoint expressed by the Law Reform Commission of Canada:

Juries have the necessary experience and common sense to evaluate the testimony before them, and in doing so to take into account such matters as its source and the fact that it is unsupported by other evidence. There is no evidence to suggest that juries are more likely to be misled by the evidence of accomplices, the victims of certain sexual offences, or young children than by any other witness and there is no reason why cross-examination and counsel's argument to the jury

62. Ibid, at p. 140.

63. Supra, n.58, at p. 11 . 
cannot expose the frailties of the testimony given by these witnesses as effectively as it exposes the weaknesses in the testimony of any other witnesses. ${ }^{4}$

On the other hand, Wakeling was critical of the Commission's view and advocated that, with respect to the testimony of accomplices and children, a warning is both necessary and sufficiently flexible to be justified. ${ }^{65}$

The Commission's view that children should be treated as individuals and not as a class of witness is preferable. However, that would not mean that a warning could never be given. If, as with adult witnesses, there appears to be a real danger (arising from a motive to misrepresent, history of false evidence or statements, etc.), then there should be a warning. The warning would not be given because the witness is a child, or a complainant, but because there is some real danger, arising from the evidence, that indicates that the testimony may be untrustworthy. The warning need not use the word "corroborate" or "danger" - what is important is that the jury be directed to evidence that should be treated with caution. This is a middle ground position that accords with the common sense position set out in Gaja, and yet would end the practice of waming juries about a child's testimony simply because the witness is a child. That would satisfy the parliamentary intention set out in s.246.4. Any other interpretation would give rise to an artificial distinction between child and adult witnesses which, in turn, would give rise to ss. 7 and 15 Charter issues. To not permit a warning in the face of "real danger", particularly when coupled with the fact that the witness may be unsworn, would arguably permit a conviction contrary to fundamental justice. The distinction in terms of a warning would be an arbitrary one based upon age.

\section{HEARSAY}

\section{A. HISTORICAL BACKGROUND}

The House of Lords stated three fundamental principles of the common law in Wright v. Tatham:

One great principle in the law is, that all facts relevant to the issue may be proved; another is, that all such facts as have not been admitted by the party against whom they were offered, or by someone under whom he claims, ought to be proved under the sanction of an oath (or its equivalent introduced by statute, a solemn declaration), either on the trial of the issue of some other issue involving the same question between the same parties or those to whom they are privy. ${ }^{66}$

The three basic principles are summarized by McCormick as follows:

1. Evidence will be upon oath which provides some guarantee of sincerity.

2. The witness will be present which enables demeanour to be assessed as part of credibility and minimizes the risk of inaccuracy.

3. The presence of the witness provides a full opportunity to cross-examine which is fundamental to a fair hearing. ${ }^{67}$ Thus, the principles encompass both a right of confrontation (to be discussed more fully below) and the hearsay rule.

64. Report on Evidence, (1977), p. 108.

65. Corroboration in Canadian Law (1977), at p. 134. See also; Bates, F., "Recent Cases on Corroboration", (1987), 6 Crim. Law Jo. 357 which supports Wakeling's view.

66. Supra, n.7, at p. 515, per Baron Parke; decision aff d 7 E.R. 559 (H.L.).

67. Supra, n. 10, pp. 726-728. 
Generally, hearsay fails to satisfy any of the three requirements, much less all three. It is therefore not surprising to find that the hearsay rule has been strictly (if not pedantically) applied. The rule has been applied notwithstanding that its effect may be to exclude the best available evidence because the declarant is dead or otherwise unavailable,$^{68}$ or that the subject matter is incapable of accurate recall and the earlier statement of the witness is likely to be the most accurate ${ }^{69}$ Nor has it mattered that the declarant is present in Court as a witness. If the witness has no memory of the event and cannot be cross-examined, then secondary evidence is inadmissible unless the requirements of past recollection recorded are met. ${ }^{70}$ Indeed, the statement is inadmissible even if given under oath; the declarant must be present for cross-examination. ${ }^{\text {" }}$

This was not always the case. In much earlier days, the jury was expected to be self-informing and act on what they knew or had heard. ${ }^{72}$ However, perceived abuse led to change once again. Perhaps the most significant event was the trial and execution of Sir Walter Raleigh who was convicted of treason on the basis of sworn affidavits which resulted not only in the loss of his head, but in significant public outcry. ${ }^{73} \mathrm{~A}$ second significant factor was the development of the adversary system in which a critical feature is the presentation of opposing witnesses with a right of cross-examination. The opportunity to cross-examine has been described by the Supreme Court of Canada as a fundamental component of natural justice and the greatest legal engine ever devised for pursuit of the truth. ${ }^{74}$

The rigidity of the hearsay rule has been softened only by the development of exceptions which were largely founded upon two principles: (a) necessity (usually death); and (b) a guarantee of trustworthiness (usually absence of motive to misrepresent which required the statement to be made before the dispute had arisen)..$^{75}$

\section{B. CURRENT CASE LAW}

The Canadian Courts have generally indicated a willingness to expand the parameters of existing hearsay exceptions. This is in marked contrast to the recent English cases. ${ }^{76}$ The "liberalization" of the hearsay rule has been most pronounced in two areas. Firstly, res gestae: the test is now spontaneity ${ }^{77}$ rather than strict contemporaneity with the event, as earlier common law required. ${ }^{78}$ It is believed that spontaneity supplies the requisite guarantee of trustworthiness being

68. Stobert v. Dryden (1836) 1 M \& W 615.

69. Myers v. D.P.P., [1965] A.C. 1001.

70. R. v. McLean (1968), 52 Cr. App. R. 80.

71. Archbold, supra, n.10, p. 859.

72. Thayer, supra, n.6, at pp. $90 \mathrm{ff}$.

73. See: M. Graham, "Indicia of Reliability and Face to Face Confrontation: Emerging Issues in Child Sexual Abuse Prosecutions" (1985) U. of Miami L. Rev. 19, at p. 62; S. Goldman, "Not So "Fimly Rooted": Exceptions to the Confrontation Clause" (1987), 66 N. Carol. L. Rev. 1, at pp. 3-4.

74. Innisfil v. Vespra et al [1981] 2 S.C.R. 145.

75. Delisle, supra, n. 36, at pp. 219-221.

76. Myers v. D.P.P. [1965] A.C. 1001; R. v. Blastland, [1986] A.C. 41.

77. Ratien v. R., [1972] A.C. 378; $R$. v. Risby, [1978] 2 S.C.R. 139; R. v. Andrews, [1987] 1 All E.R. 513.

78. Teper v. R., [1952] A.C. $480 ; R$. v. Bedingfield (1879), 14 Cox C.C. 341. 
the converse of a concocted, or constructed statement in which motives or others' memories may play a part. Secondly, declarations in the course of a duty have been the subject of numerous cases. The clear trend has been to admit such documents because the duty supplies sufficient trustworthiness. The documents usually record matters of detail which could not be normally remembered in any event and for which there is no apparent purpose to cross-examination. ${ }^{79}$

However, this trend toward liberalization has not assisted in child sexual abuse cases. Obvious difficulties arise with: (a) the pre-verbal child victim, where no hearsay exception would assist; (b) the victim who has been pressured into recanting the allegation: the child could be cross-examined on a prior inconsistent statement but the generally held view is that unless the previous statement is adopted (acknowledged to be true), it goes only to credibility:;0 and (c) the child who is traumatized and cannot be made to, or coherently heard, to testify: even if this were to satisfy an expanded test of unavailability, the problem remains that the prior declaration was made at a time after the dispute arose. Thus, in the criminal law sphere, prior statements of a witness have been of limited utility. These statements are useful to rebut allegations of recent fabrication, or possibly as evidence of recent complaint, ${ }^{81}$ and may be used before Court to refresh memory, or to refresh memory in Court provided that the requirements of present memory revived are met. ${ }^{82}$ Additionally, they may be used as evidence where the witness testified to an absence of memory provided that the requirements of past recollection recorded are met. ${ }^{83}$ The Courts have also indicated a willingness to apply a less strict test of spontaneity for the purpose of the res gestae exception, particularly where the child is very young and the details of the sexual act disclosed are beyond their knowledge. ${ }^{84}$

The rules in criminal proceedings have not paralleled those in civil cases involving children, but the latter are distinguishable on the basis that such cases are not part of an adversarial proceeding, and therefore the hearsay rule is not applicable..$^{85}$ In any event, some cases have indicated that a judgment should not be founded on hearsay evidence going to the central issue, if that is the only evidence. ${ }^{86}$

In criminal proceedings, the child is as equally vulnerable to the hearsay rule as the adult witness, perhaps an ironic form of equality. The pressure for reform,

79. R. v. Penno (1975), 35 C.C.C. (2d) 266; R. v. Schantz (1983) 34 C.R. (3d) 370.

80. In $R$. v. Rouse and McInroy (1979), 42 C.C.C. (2d) 481, Estey, J. indicated that even absent adoption it was evidence of the truth of the statement, but both the Alberta Court of Appeal in $R$. v. Smith (1986), 66 A.R. 195, and the Nova Scotia Court of Appeal in Barnes v. R. (1985), 44 C.R. (3d) 67 declined to follow this obiter comment.

81. See: $R$. v. Paige (1984), 12 C.C.C. (3d) 520 for a review of the rules in relation to recent complaint.

82. The critical question is whether the record must have been made at a time when memory was fresh. The older common law indicated that such was not a requirement. See: Delisle, supra, n.36, at pp. 138-142. This view was supported in R. v. Bengert (No.2) [1979] 1 W.W.R. 472, aff d (1980) 53 C.C.C. (2d) 481. However, the Ont. C.A. ruled in R. v. Quoydowski (1973), 10 C.C.C. (2d) 434 that contemporaneity was required.

83. In $R$. v. Rouse \& McInroy, supra, n. 78 those were set out as: (a) record made when memory was fresh; (b) witness asserts the truthfulness of the statement.

84. R. v. Khan, supra, n.37, at p. 19.

85. Official Solicitor v. K., [1965] A.C. 201; Re N.M.H. (1985), 59 B.C.L.R. 359; Re D.R.H. (1985) 58 B.C. L.R. 103.

86. Young v. Young (1985) 48 R.F.L. (2d) 390. 
then, has concentrated very heavily on this rule, with advocates for wide-open hearsay ${ }^{87}$ opposed by those who view the right of cross-examination as fundamental. There are few issues that are so revealing of strong competing interests.

\section{REFORM UNDER BILL C-15}

By s.15 of Bill C-15, a new s.643.1 of the Criminal Code is enacted which authorizes the use of videotaped statements. The section has several components: (a) where an accused is charged with one of the previously enumerated offences and, (b) the complainant was at the time the offence was committed under eighteen years of age, (c) a videotape made within a reasonable time of the alleged offence, in which the complainant describes the acts complained of, may be shown if the complainant adopts the content of the videotape while testifying. The emphasized words are critical and will create problems of interpretation which will be discussed more fully.

The first question that arises is the purpose for which the evidence is admissible. As previously noted, a prior statement could be used to rebut recent fabrication, to refresh memory, or as past recollection recorded. Under the current law, there is no reason to believe that a videotaped statement could not be used for similar purposes without specific legislative authority. It is simply a matter of the form of the statement. At the same time, a videotaped statement could not be used under the res gestae exception because it would clearly lack the requisite spontaneity.

Additionally, it could have been used as evidence of recent complaint. However, as previously noted, the rules in relation to recent complaint are abrogated by s.246.5. In R. v. Paige, Ewaschuk, J. held that this means that such evidence is neither required or admissible unless it meets the test for res gestae, or is required to rebut an allegation or recent fabrication. ${ }^{88}$ If that interpretation is correct, then one of the most useful purposes of such evidence has been, albeit unwittingly, eliminated.

A narrow interpretation of the section would be that the usage of the statement is confined to the situations recognized at common law (absent recent complaint). The liberal interpretation is that the section attempts to create a new hearsay exception or, to be more accurate, expand an existing hearsay exception: past recollection recorded. Again, the current requirements of past recollection recorded are: (a) made when memory was fresh (satisfied by the words "soon after"); (b) the witness's memory has failed (not required under s.643.1); and (c) the witness attests to the truth of the statement (required by the new section). Thus, at first sight, the section does not entail a major change. A new exception is not created, but rather, an established exception is altered in one particular. Furthermore, the right of cross-examination is preserved, which is critical.

The American experience also shows that a videotaped statement may have other beneficial effects: (a) it encourages confessions and guilty pleas; (b) it facilitates treatment of the offender; (c) it curtails recanting by the complainant; (d) it preserves

87. J. Spencer, “Child Witnesses and Video Technology: Thoughts for the Home Office”' (1987), 51 Jo. of Crim. Law 437.

88. Supra, n.81. 
the statement at a time when memory is fresh and outside influence is somewhat less; and (e) it has been useful as an aid to expert testimony.$^{89}$ At the same time, it must be said that weaknesses have been found to include: (a) problems of cuing and suggestibility ${ }^{90}$ and (b) it does not reduce trauma for the witness. ${ }^{91}$ These weaknesses certainly appear in s.643.1, but other weaknesses do as well, stemming from awkward drafting of the section. The weaknesses in the section are as follows:

1. It will not necessarily reduce trauma. The subject of the traumatic effects of testifying is a controversial one. Some professionals suggest there is a negative impact on the child while others have said the opposite, indeed, that it may be therapeutic given proper preparation and follow up..$^{22}$ The problem with the current state of research is that it is anecdotal. In Hocheiser v. Superior Court of California, it was stated by the Court of Appeal:

In our research of the professional literature on the matter, we have not discovered any study based on empirical data, which deals with the damaging psychological effect of giving testimony in the presence of the jury and the accused, on the sexually abused child. Rather, we found that such literature merely contains generalized statements to this effect. 93

But, even assuming traumatic effect, this section will not assist. The child must appear in Court to testify as to the truth of the content, and be subject to crossexamination. Why then is the section limited to complainants who were less than eighteen at the time the alleged offence was committed? A number of American states have recognized that trauma may affect adults, dependent upon the nature of the offence. Sexual offences and kidnapping are two examples where videotaped statements have been authorized. ${ }^{94}$ Furthermore, the section ignores one situation where a videotaped statement by an adult may be imperative as being the best available evidence: the mentally deficient complainant. Therefore, the section is not broad enough, nor will it serve to reduce trauma for witnesses under the age of eighteen.

One gets the impression that the idea of videotaped evidence of a child was hastily borrowed from the United States, where about 25 states have enacted legislation providing for videotaped evidence of a child.${ }^{95}$ However, that legislation was intended to reduce trauma, for videotaped statements were to be used as an

89. See Graham, supra, n.73, at p. 66. It is important to note that it is useful for expert testimony only if the statement is admissible as a hearsay exception. The Supreme Court of Canada has ruled that an expert's opinion is valueless to the extent that it relies upon hearsay, in the absence of independent evidence. See: $R$. v. Abbey, (1983) 68 C.C.C. (2d) 394; R. v. Babcock (1984), 16 C.C.C. (3d) 26.

90. R. Eatman, "Videotaping Interviews With Child Sex Offence Victims" (1986), 7 Children's Legal Rights Jo. 13.

91. See Graham, supra, n.89.

92. L. Gerliner and M. Barbieri, "The Testimony of the Child Victim of Sexual Assault" (1984), $40 \mathrm{Jo}$. of Social Issues, at pp. 130-31, 135; L. Elamen et al, "The Adolescent as a Witness in a Case of Incest; Assessment and Outcome" (1986), 25 Jo. of the Am. Acad. of Child Psych. , 4: 461.

93. 208 Cal. Reptr. 273 (1985), at p. 283. By contrast, the Scottish Law Reform Commission was persuaded by the available research that the stress on children may be greater and therefore less acceptable than that which an adult faces: see The Evidence of Children and Other Potentially Vulnerable Witnesses, Discussion Paper No. 75 (June, 1988).

94. J. Buckley, "Introduction: Background and Overview of Child Sexual Abuse"' (1985), U. of Miami L. Rev. 5, at p. 11. Additionally, the Scottish Law Reform Commission was of the view that the usage of such statements should not be offence specific with respect to child witnesses. They were of the view that a child is as likely to be traumatized if the case involves a break and enter into the home as when it involves a sexual assault.

95. Graham, supra, n.73, at p. 82. 
alternative to oral testimony where the child was unavailable as a witness (unavailability including trauma). ${ }^{96}$ However, some state Courts have ruled this unconstitutional. ${ }^{97}$ Accordingly, what we have borrowed is half an idea.

2. It is not clear what the requisite age is. $\mathbf{s} .643 .1$ provides that the statement may be used where the complainant was less than eighteen years at the time the alleged offence was committed. Clearly, the witness may be more than eighteen at the time of trial. However, s.643.1 also requires that the statement be taken within a reasonable time after the alleged offence. This would place some restraint on the age of the witness. For example, if a seventeen year old gave a statement soon after the offence, and a year or more passed until trial, the videotape could be used. This seems a logical provision designed to prevent delays in the process of frustrating the usage of the statements. However, if a twelve year old child complained of being sexually abused at age five, then, it would seem that the videotape could not be used. In fact, it is not uncommon for victims to conceal the abuse for years after the incidents, particularly in cases where the offender utters threats. ${ }^{98}$ Thus, in determining whether the tape is admissible, the limiting words of "reasonable time" will have to be borme in mind no matter how incongruous the results (i.e., the twenty year old witness may be able to use the statement, but the twelve year old witness might not). It would seem to require a voir dire at which the child may have to testify. Facts such as age, reasons for delay, presence or absence of threats or pressure, and presence or absence of improper motives, would be important considerations. This might be compared to the simplicity of the Washington statute, which authorized the usage of videotapes, if the witness was less than ten years of age at the time of testifying. ${ }^{99}$ In New South Wales and South Australia, the age is sixteen. ${ }^{100}$

3. The phrase "within a reasonable time" is ambiguous. American legislation focuses on the issue of reliability in three senses: (a) accuracy of memory by requiring the judge to examine the time factor; (b) absence of selective editing by requiring the judge to examine the context in which the statement was made; and (c) absence of pressure, suggestion or cuing by requiring the judge to examine the circumstances of statement. ${ }^{101}$ The Texas statute is perhaps the most rigorous, requiring: (a) that no attorney for either party be present; (b) proof of integrity of the tape; (c) that the statement was not made in response to questioning calculated to elicit a particular statement; (d) voice identification; (e) that the person who conducted the interview be present as a witness; and (f) that the recording be made available to the accused prior to trial. ${ }^{102}$

By contrast, the Canadian provision focuses on time only, but without specific guidelines. Disclosures of child abuse may require several interviews. It is doubtful

96. People v. Gomez 26 Cal. App. (3d) 225; Warren v. U.S. 436 A. $2 \mathrm{~d} 821$.

97. Long v. State of Texas 694 S.W. $2 d 185$.

98. E. Cacciola, "The Admissibility of Expert Testimony in Intrafamily Child Sexual Abuse Cases" (1986), 34 U.C.L.A.L. Rev. 175, at pp. 181ff.

99. Wash. Rev. Code, 9A 44:120 (1974).

100. Supra, n.44, at pp. 50-54.

101. See for example, S. 90.803(23) Fla. Stat. (Supp. 1985); Wash. Rev. Code, 9A 44:120 (1974).

102. Texas Criminal Procedure Code Ann., ant. 38.071(2) 1985, s.2(a). 
that Parliament intended that all of the interviews be recorded, or that the earliest interview be taped and shown, which raises the issues that the American legislation attempts to deal with, and s.643.1 ignores. Defence counsel will undoubtedly argue that a statement made within a reasonable time means the time when the disclosure was first made, not the statement made at the end of several interviews. This is doubtful. If that was the intention, Parliament could have used words such as "at the first reasonable opportunity." However, factors such as those contained in the Texas statute could be considered in determining whether the statement may be used. Alternatively, the defence will argue that they should have access to records of other interviews to ensure the integrity of the taping process (i.e., that it is not a staged production). This would be a discretionary matter for the trial judge that should be exercised in accordance with current rules for disclosure of prior statements of a witness.

4. The videotaped statement is limited to a statement of the acts complained of. This would normally mean the act(s) alleged in the information or indictment. In turn, that would mean that the remainder of the witness's evidence would have to be given in the normal fashion. Most importantly, it would mean that similar fact evidence from the complainant or another witness could not be given by way of videotape, because it would not be the act complained of. Thus, details of events which may be as, or more, embarrassing for the witness to relate as those comprising the offence would have to be given without the usage of videotape.

5. Form. In Hocheiser, the Court expressed concern with the possibility of distortion throughout the videotape process, noting that filming techniques are such that a witness may be made to appear fragile or strong, and that credibility may be unduly enhanced. ${ }^{103}$ Additionally, the problems raised above such as cuing, suggestibility, and the presence of Crown counsel at the interview, are not addressed in the legislation. Nevertheless, a trial judge could examine the context and circumstances of the statement in the exercise of the normal discretion set out in R. v. Wray, ${ }^{104}$ and could permit the integrity of the taping to be questioned under the normal rules for the introduction of videotaped evidence. ${ }^{105}$

It is also not clear whether the statement must be an oral description, or whether it may be accompanied by demonstration, such as the usage of anatomically correct dolls. Section 643.1 simply says: "describes the acts complained of." Anatomical dolls were originally intended as a diagnostic tool, particularly for pre-verbal children. That is, they "can assist the child in relating experiences and feelings that might not be accessible through more traditional methods." 100 Therefore, should it be permitted as a form of dramatic description, particularly if the child is capable of verbalizing the event without assistance? The most sensible way to approach

103. Supra, n.93, at pp.278-279.

104. [1970] 4 C.C.C. 1.

105. The requirements are: (a) accuracy in representing the facts, (b) faimess and absence of intent to mislead, (c) verification. See: E. Goldstein, "Photographic and Videotape Evidence" (1987), 6 Civ. J.Q. 312; R. v. Smith (1986) 71 N.S.R. (2d) 229; R. v. Leaney (1988), 38 C.C.C. (3d) 265.

106. Besee, et al, "Allegations of Child Sexual Abuse in Child Custody Disputes; A Therapeutic Assessment Model" (1986) Am. Orthopsych Jo. 560, at 566. The Scottish Law Reform Commission, supra, pp. 61-62 was also concemed about dangers associated with the usage of dolls. Their view was that if "used with care" the technique should be permitted. 
this problem would be to apply the same rule to videotapes as that for giving testimony in Court. That is, if the judge is satisfied that it is necessary, and would assist the child in giving the evidence, it would be admissible. This would assist with very young children who simply may not have the necessary language. On the other hand, if the child can verbalize, and the usage of dolls simply appears to be used to dramatize the statement, it should not be permitted. This would accord with current cases on videotape where dramatic effects such as slow motion are not permitted. ${ }^{107}$

In $R$. v. Thompson, a recent unreported decision (Feb. 27, 1989) of the Alberta Queen's Bench, McKenzie, J. provided an obiter (the accused was convicted) decision to the effect that the videotape provision contravened ss. 7 and 11(d) of the Charter of Rights and Freedoms. In his view, fundamental justice incorporates the notion that an accused may not be convicted upon unswom evidence unless such evidence falls within a recognized hearsay exception. With respect to s.1, he believed that there were three fundamental flaws:

1. Arbitrary age: in his view, the age of eighteen was unwarranted as such persons are nearing adulthood and is not specifically directed to the problems of young witnesses. There may be a problem with age but, as suggested earlier, the greater problem is that it would exclude those over 18 where the videotaping would be of assistance, the autistic child, for example.

2. Absence of reliability: he was concerned that the videotapes may be put together by persons with an interest in the outcome. Again, in the United States, guarantees of reliability are built into the legislation but that is because the videotape was intended as a true hearsay exception replacing the witness. Where the witness is present for cross-examination it is less imperative. Factors going to unreliability could, as earlier suggested, weaken the evidence or, if completely unreliable, be excluded pursuant to the common law judicial discretion.

3. Disadvantage to the accused: while the accused may cross-examine it would be an illusory right if the witness refused to answer. To the extent that the refusal is due to trauma this in fact is some evidence of the necessity for such legislation. If wilful, that problem can occur even without videotaping; as in the case of a witness who refuses to answer following examination in chief.

While the reasons for judgment are not particularly convincing it clearly indicates that the section will be the focus of Charter litigation as it has been in the United States. The real frailty of the section is that it is badly drafted and insufficiently protects vulnerable witnesses.

\section{CONFRONTATION}

\section{A. HISTORICAL BACKGROUND}

The right of an accused to appear at his or her own trial, face to face with accusers, was a gradual development of the common law. While dangers of hearsay evidence

107. Supra, n.105; $R$. v. Maloney (1976) 29 C.C.C. (2d) 431 . The issue has arisen in English civil cases where interviews have been conducted using anatomically correct dolls. Thusfar the evidence has been accepted cautiously (see: $\operatorname{Re} M$, [1987] 1 F.L.R. 293) or with hostility, i.e., no evidential weight to be given to it (see C. v. C., [1987] 1 F.L.R. 321). 
were recognized as early as 1202 A.D., such evidence was freely admitted when trial by jury was established. ${ }^{108}$ Eventually, hearsay became admissible only after direct evidence was given, and only as corroboration. ${ }^{109}$ Eventually, by statute, the right of the accused to hear directly the evidence of witnesses was affirmed."10

Again, in part, this development stemmed from the public outcry that followed the trial of Sir Walter Raleigh. "' However, it must not be thought that the right to be present and hear witnesses is concerned only with the hearsay rule. The conventional view is that the foundation of the American sixth amendment confrontation right was a reaction to the perceived historical abuses of admitting hearsay evidence. ${ }^{112}$ But, the right protected is broader than ensuring a right of crossexamination. In Mattox v. United States, the Supreme Court stated:

The primary objective of the constitutional provision in question was to prevent dispositions or ex parte affidavits, such as were sometimes admitted in civil cases, [from] being used against the prisoner in lieu of a personal examination and cross-examination of the witness in which the accused has an opportunity, not only of testing the recollection and sifting the conscience of the witness, but of compelling him to stand face to face with the jury in order that they look at him, and judge by his demeanour upon the stand and the manner in which he gives his testimony whether he is worthy of belief. 113

Thus, the historic purpose for the right extended beyond the absence of crossexamination (which is the primary defect of hearsay evidence). Salhaney asserts that eventually the English common law protected similar values. ${ }^{114}$

\section{B. CURRENT CASE LAW}

The right of an accused to attend to the proceedings is contained in $\mathbf{5 . 5 7 7}$ of the Criminal Code. Its mandatory language has been interpreted as providing both a right and imposing a duty upon the accused to attend the trial. ${ }^{115}$ The only limitation upon this right has been that the accused must not be unruly in Court, and if unruly, may be excluded. ${ }^{116}$ The Canadian cases have not had to deal with a situation in which the accused was excluded from the trial, apart from the rare unruly defendant situation. Given s.577, the situation could not arise. The typical situation where the issue has arisen is where some discussion has occurred which might have a bearing on the outcome of the case. In that situation the accused has a right to be present, as opposed to where the discussion deals with a minor administrative matter. ${ }^{117}$ If the discussion affects a "vital interest", the accused must be

108. J. Tumer, Kenny's Outlines of Criminal Law (1966), at p. 748.

109. Bbid.

110. $11 \& 12$ Vic. c. 42 .

111. Supra, n.73.

112. Bbid.

113. 156 U.S. 237 (1895), at pp. 242-43. See also: Kirby v. U.S. 174 U.S. 47 (1890).

114. Salhaney, Canadian Criminal Procedure, 4th ed., (1984), at pp. 314-15. See also: Coy v. State of lowa (1988), 108 West's Sup. Ct. Reporter 2798, at p. 2800 where Scalia, J. traces the common law roots of the right of confrontation.

115. R. v. Ginoux (1971) 15 C.R.N.S. 117, at p. 119, per Brossard, J.A.; affd 16 C.R.N.S. 256; R. v. Hertrich et al (1982), 67 C.C.C. (2d) 510, at pp. 526-27, per Martin, J.A., leave to appear refused 45 N.R. 629.

116. Ginoux, ibid.

117. Supra, n.115. 
present. ${ }^{118}$ However, the Courts have discussed the nature of the right being protected. In $R$. v. Hertrich, Dubin J.A. stated:

\begin{abstract}
The essential reason the accused is entitled to be present at his trial is that he may hear the case made out against him, and having heard it, have the opportunity of answering it . . . The right of the accused to be present at his trial, however, also gives effect to another principle. Faimess and openness are fundamental values in our criminal justice system. The presence of the accused at all stages of his trial affords him the opportunity of acquiring first-hand knowledge of the proceedings leading to the eventual result of the trial. The denial of that opportunity to an accused may well leave him with a justifiable sense of injustice. Indeed, in my view, an examination of the Canadian decisions shows that the latter principle is, in fact, the implicit and overriding principle underlying those decision (emphasis added). For example, in Paquette v. The Queen, [1979] 2 S.C.R. 26 . . I cannot think that it could realistically be contended that the transmission to the jury by the judge, after consulting counsel, of his written answer that he was unable to comply with their request to be supplied with a part of the charge, could have affected the accused's ability to defend himself, but the communication between the judge and the jury, in the circumstances, violated the second principle. In Ginoux v. The Queen (1971) 15 C.R.N.S. 117 . . the ruling made by the judge in the absence of the accused was in his favour. ${ }^{119}$
\end{abstract}

There are, therefore, two principles protected by the right of attendance: (a) the principle that an accused has a right to hear the case to be met and to answer it (including the right of cross-examination), and (b) the principle of fairness and openness which requires that an accused be present so that first hand knowledge of the proceedings may be acquired. It is the second principle which is primary. This was confirmed by the Supreme Court of Canada in $R$. v. Barrow which described the right to present as a "fundamental principle" of criminal law. ${ }^{20}$ Significantly, this parallels the articulation of values protected by the sixth amendment which has important implications for reform in Canada. Arguably, any reform must leave both principles intact so as not to violate s. 7 of the Charter. That issue arises because the rationale for the right of attendance (as expressed by the Canadian Courts) bears close resemblance to the rationale for the right of confrontation as expressed in cases such as Mattox by the American Courts.

\title{
C. REFORM UNDER BILL C-15
}

The impetus for reform has been the concern that children, when confronted by the accused, may be traumatized or intimidated, and therefore unlikely to give a full account of the incident. Additionally, if the accused is a parent or other relative of the child, there is concern that the child may not wish to testify at all. The Law Reform Commission of Victoria noted that testifying is a significant source of distress to any complainant, but: " [i]t is likely to be particularly so for children in sex abuse cases, where the accused is commonly a person occupying a position of authority over the child." 121 In theory, then, by reducing the confrontation aspect of the trial, the child should feel less inhibited. To this end, reform has taken three forms:

1. The surrogate witness system. The chief features of this form are: (a) the child is interviewed at an early stage by a specially trained interrogator; (b) the child

118. Vezina; Cote v. R. 49 C.R. (3d) 351, at pp. 357-59.

119. Supra, n.115, at p. 537 .

120. (1988), 38 C.C.C. (3d) 193, at pp. 202-04, per Dickson, C.J.C.

121. Supra, n.44, at p. 44 . 
is not required to testify unless the interrogator consents; and (c) if the child does not testify, the interrogator presents the evidence. ${ }^{122}$

2. Modifying the Courtroom. In New South Wales, legislation permits the modification of the Courtroom so that furniture is of appropriate size for children, screens are used which prevent the accused and child from viewing each other, and robes are not worn by counsel. ${ }^{123}$ Recently, English Courts have adopted similar measures without the authorizing legislation, and the Scottish Law Reform Commission has made several specific recommendations along the same lines. ${ }^{124}$

3. The use of videotaped statements and closed circuit television. About 25 American states now authorize such measures, ${ }^{125}$ as does New South Wales. ${ }^{126}$

Bill C-15 adopts, with modifications, the latter system. An amended s.442(2.1) of the Criminal Code authorizes the following: (a) notwithstanding the right of attendance under s.577, if the accused is charged with one of the enumerated offences; (b) the complainant is under the age of eighteen at the time of trial; (c) the judge or justice may order that the complainant give their testimony from outside the Courtroom, or behind some device such as a screen; (d) provided it is necessary to obtain a full and candid account of the acts complained of; and (e) provided the accused, counsel, judge and jury are able to watch the proceedings by closed circuit television.

The section thus requires the child to be present but authorizes the separation of the accused and complainant. It is the major innovation to reduce trauma for the witness although it bears repeating that very little research has been done on the psychological effects of the Courtroom. A major problem of pre-trial pressure on the child to recant the accusation is not addressed by the section. The problems presented by the section are as follows:

(a) Confrontation Right. By requiring the presence of the child, and by permitting the accused to view the proceedings (albeit indirectly) and communicate with counsel, s.442(2.1) is substantially different than the American legislation which contemplates the usage of videotaped evidence as a substitute for oral evidence. The Canadian provision requires the child to be present as a witness. Although there is not yet a Supreme Court decision on point, the American legislation has generally been struck down on the ground that it violates the accused's confrontation rights.

The more difficult question is whether confrontation requires "eyeball to eyeball" confrontation, or whether permitting the accused to view the proceedings is sufficient. It is an important question, because given the rationale underlying the

122. Ibid, at p. 59.

123. Ibid, at pp. 53-54.

124. The Guardian, "Screens Shelter Children in Sex Abuse Cases" (Oct. 21, 1987), at p. 1; The Times, "Child Abuse: Court Dilemma for Law Makers" (Oct. 25, 1987), at p. 40. The Scottish Law Reform Commission, supra, n.93, pp. 37ff, specifically recommended: robes be removed, children give testimony at a table rather than from the witness box and that the judge and counsel sit at the same table, appropriately sized fumiture be used, special waiting rooms be created, microphones be used to amplify voice, and that all child witnesses be given a tour of the courtroom prior to testifying.

125. Supra, n.73, at p. 11.

126. Supra, n.44, at p. 56. 
right of an accused to attend (as stated in Hertrich), a right of confrontation is arguably contained within s.7 of the Charter. The American Courts have used a similar test for constitutionality ${ }^{127}$ as has the Supreme Court of Canada ${ }^{128}$ (i.e., if a right has been violated, the state bears the burden of demonstrating a compelling state interest).

In California v. Green ${ }^{129}$ and Ohio v. Roberts, ${ }^{130}$ the Supreme Court established that the confrontation right was not infringed in circumstances where the witness was unavailable and the hearsay fell within a "well rooted" hearsay exception. The state courts have had to apply these rulings in determining the validity of child abuse legislation with mixed results. ${ }^{131}$ The following procedures have been upheld:

(i) Reading an excerpt from a preliminary inquiry transcript where the accused's counsel had cross-examined. ${ }^{132}$

(ii) Allowing hearsay statements which fell within the res gestae and statements as to mental or physical conditions exceptions. ${ }^{133}$

(iii) Permitting a deposition to be read where the witness was unavailable (the witness had suffered a stroke) and the accused and counsel were present for the taking of the deposition and could cross-examine. ${ }^{134}$

(iv) Statements made by a two-and-a-half year old child in response to leading questions. The Washington Court of Appeal held that the witness was "not available" because she lacked memory of the event. Where such statements were not part of a firmly rooted hearsay exception, the Washington statute requires particularized guarantees of trustworthiness: time (broader than res gestae), content (leading is of concern but in this case the language used was appropriate for a child of that age and therefore it appeared to be her statement), and context (not the result of fabrication or influence). ${ }^{135}$

(v) Statement where the child was unavailable and where there were sufficient guarantees of trustworthiness. In State v. Myatt, the Kansas Court of Appeal ruled that where the child was unavailable because she was disqualified as a witness, and where the hearsay statement was corroborated by medical evidence, the right of confrontation was not infringed. The Kansas statute required that the statement be "apparently reliable". The Court indicated that factors of reliability included: age, circumstances of the event, language used, physical evidence, relationship of the accused to the child, the child's family, school and peer relationships, and motive to misrepresent or falsify a statement. ${ }^{136}$

127. Ohio v. Roberts, 448 U.S. 56 (1980); Long v. Texas, supra, n.97.

128. R. v. Oakes (1986) 24 C.C.C. (3d) 321.

129. 26 U.S.S.C.R. 489 (1970).

130. Supra, n.127.

131. Graham, supra, n.73.

132. Califomia v. Green, supra, n.129.

133. U.S. v. Iron Shell 633 F. $2 d 77$ (1980).

134. U.S. v. Tunnell 667 F. $2 \mathrm{~d} 1182$.

135. Washington v. Slider 688 P. 2d 538 (1984).

136. Supra, n.4. 
The following procedures have been held to be unconstitutional:

(i) The use of separate rooms. Placing the accused and witness in separate rooms violates the right of confrontation. ${ }^{137}$

(ii) Usage of videotapes where the witness is available. In Texas, the statute requires guarantees of trustworthiness but does not require that the witness be unavailable to give evidence. The Court ruled it violated the right of confrontation, although the child could be called and cross-examined. ${ }^{138}$

(iii) Procedures whereby the accused could hear the evidence but not see the witness. In Herbert v. California, the trial court had ordered a rearranging of the courtroom to prevent the accused seeing the child. The Court of Appeal held that, in the absence of evidence that the accused had intimidated the child, or that the child was actually suffering discomfort, this procedure was impermissible. ${ }^{139}$

(iv) The usage of screens which prevent "face to face" confrontation. ${ }^{140}$ The majority ruled that the right of confrontation, flowing from historical notions of fairness, requires that the accused be able to see the witness and that the witness be able to see the accused. ${ }^{141}$ In a separate concurring judgment, O'Connor and White, J. deal somewhat more directly with the question of exceptions (left open by the majority). They restrict their ruling to screens and impliedly approve of the usage of closed circuit television (authorized in 33 states) or one way video systems where the judge, counsel, and accused are in a room and the child's testimony is broadcast into another room for the jury. ${ }^{142}$ Similarly, if a Court makes a casespecific finding of necessity (as required in 4 states) then the strictures of the confrontation clause could give way to the compelling policy of protecting child witnesses. ${ }^{143}$ The dissent was of the view that "face to face" confrontation did not necessitate the witness seeing the accused, and given compelling evidence of the psychological harm to children in testifying, the right of confrontation must give way to a procedure which could best satisfy the truth finding function of the trial. ${ }^{144}$

While it is not at all clear that the Canadian Courts will follow the U.S. path, s.7 and s.11(d) Charter arguments will raise many of the same issues. From the above, a number of U.S. principles may be extracted:

(i) If the statements fall within recognized hearsay exceptions, the right of confrontation is not affected. There is no reason to believe that the situation should be any different in Canada.

137. U.S. v. Benfield 593 F. 2d 815; Hocheiser v. Califormia, supra, n.93.

138. Long v. State of Texas, supra, n.97.

139. 172 Cal. Reptr. 850.

140. Coy v. State of lowa, supra, n.114.

141. Ibid, at p. 2802, per Scalia, J. It is ironic that one of the factual allegations in the case was that the assailant had entered the girls' tent at night, shone a flashlight in their faces and wamed them not to look at him.

142. Ibid, at p. 2803-04.

143. Ibid, at p. 2806.

144. Ibid, at p. 2808-09, per Blackman, J. 
(ii) A statute that authorizes the receipt of hearsay statements does not infringe the right of confrontation, provided the statute imposes conditions of unavailability and guarantees of trustworthiness. The corollary is that a statute not imposing such conditions is unconstitutional. Clearly, an arguable issue is raised in Canada. Assuming a hearsay exception has been created, neither unavailability nor guarantees of trustworthiness are required. Unless the provision can be interpreted as requiring those conditions there is a potential problem under 5.7 of the Charter.

(iii) Although the statute is valid, the facts of each case require that the child be unavailable and that there is a sufficient guarantee of trustworthiness. This is a question of fact and law for the trial judge to determine.

(iv) Statutes, or Court adopted procedures, that exclude the accused from the Courtroom, or prevent face to face confrontation, may be unconstitutional. Approximately 33 states legislatively authorize the usage of closed circuit television systems. Again, Bill C-15 authorizes the separation of the accused and complainant. Such procedures do not appear to offend the purposes served by confrontation: the right of cross-examination is preserved, the accused acquires first hand knowledge of the case, the accused hears the case to be met, and may see the witness. Unless confrontation includes a requirement of the witness seeing the accused (as prevented by the usage of screens), the procedures are not necessarily offensive, particularly if it is an effective means of reducing trauma for the child witness. On this point, the dissent in Coy v. Iowa contains the more compelling reasoning. The major problem, however, may be that the procedure violates the presumption of innocence (an issue not discussed by the majority in Coyv. lowa).

(v) The presumption of innocence. In Hocheiser, the Court held that authorizing the exclusion of the accused from the Courtroom may violate the presumption of innocence. This is because, notwithstanding a direction to the jury, a jury may draw the inference that the procedure is adopted because the child genuinely has something to fear from the accused. The Court drew parallels with the unnecessary usage of physical restraints on an accused. ${ }^{145}$ For this reason, Graham recommends that the procedures used must have the appearance that it is a normal procedure in every case involving children. ${ }^{146}$ In reviewing the New South Wales legislation, the Law Reform Commission of Victoria observed:

\footnotetext{
The use of certain altemative arrangements, such as screening the child from the accused, might be regarded as reflecting on the accused's innocence or guilt. To counter this possibility the legislative provides that the judge may, at the request of the accused:

- inform the jury that the use of the altemative arrangement is standard procedure required by law; and

- wam the jury not to draw any inference or give the evidence any greater or lesser weight because of the use of the alternative arrangements. ${ }^{147}$
}

While the efficacy of jury warnings has been the subject of some criticism, the appearance of normality may be critical. The warning would not be possible in Canada because it is not a standard procedure. Indeed, the provisions of s.772(2.1)

145. Supra, n.93.

146. Supra, n.73.

147. Supra, n.44, at p. 54. 
potentially aggravate the problem. It requires the trial judge to rule on whether it is necessary to order to obtain a "full and candid" account. Clearly, this voir dire must be conducted in the absence of the jury, but the wording implies that the separation of the accused and child will lead to a truthful account, which may be perceived as pre-judging the issue. The New South Wales approach would have been far preferable, or a case specific necessity finding that trauma might prevent the witness from testifying, without comment on the credibility of evidence.

(b) The problem of mechanics. The use of the special procedures is dependent upon the availability of the necessary electronic equipment. In all likelihood, its use will be restricted to certain centres, with less intrusive measures such as screening being used elsewhere. However, some logistical problems will arise such as the possible failure of the system. If the child's evidence cannot be seen and heard, there may be a mistrial. It is not clear how identification is to be achieved. Presumably the complainant will have to be brought into the courtroom for that purpose. It is of interest to note that the Scottish Law Reform Commission has recommended that a child witness should be allowed to make an out of court identification (lineup procedures) and would not be required to make the identification in court. ${ }^{148}$ This reform would have been sensible in Canada given that the courts have accepted that out of court identification procedures carry greater weight than dock identification. ${ }^{149}$

Furthermore, if the defence wishes to cross-examine the complainant on the videotaped statement (assuming it has been used), it may be necessary to bring the complainant into the courtroom for that purpose. That would be necessary to direct the child's attention to that portion of the videotape on which the cross-examination is being focused.

It is also not clear when the order is to be made: before the child is sworn, or promises to tell the truth, or after that issue is determined. The section contemplates that evidence is to be given. Presumably, this means that this issue of competency, if any, would have to be determined first.

A further question arises as to the evidence necessary to found the order. It could be done by consent. But, absent consent, it would seem to require a voir dire (in the absence of the jury) with perhaps the child and experts testifying. However, the child would have to testify in the presence of the accused since the order cannot be made until the pre-condition is met! The section required much more careful drafting and specific rules.

\section{CONCLUSION}

Bill C-15 proposes fundamental changes in each of the four areas discussed in this paper. The motivation for reform is worthy because it seeks to rid the law of antiquated notions about children. Change is long overdue. It is apparent that an attempt has been made to recognize the interests of the child in a more forceful manner.

The frailty of the proposed reforms is that it follows the conventional view of legal reform, i.e., that reform requires a balancing of interests, without addressing

148. Supra, n.93, p. 81 .

149. R. v. Swanston (1982), 65 C.C.C. (2d) 453 (B.C.C.A.). 
the fundamental question of whether balancing is possible. Are the disparate rights of the accused and children so opposed that balancing is impossible? These reforms tinker with traditional safeguards for the accused through vague wording and ill considered options, leaving it to the courts to grapple with problems of interpretation and Charter challenge. As they stand now, the provisions increase the number of voir dires required, do little to reduce trauma, and do not address the problem of the pre-verbal child or mentally handicapped victim at all. The most likely effect will be full employment for lawyers for the next few years.

It is true that the reforms indicate a willingness to ensure that a few more victims do not leave the criminal courts unvindicated. Yet, any real commitment to victims of child abuse is missing. We again seek to resolve the problem through the criminal courts (necessitating an unsatisfactory balancing act from both perspectives) rather than demonstrating commitment by providing adequate resources for the prevention of child abuse and the treatment of the child, the family, and offenders. 